\title{
Adult Feeding and Mating Effects on the Biological Potential and Parasitism of Trichogramma pretiosum and T. acacioi (Hym.: Trichogrammatidae)
}

\author{
Dirceu Pratissoli ${ }^{1}$, Harley Nonato de Oliveira ${ }^{1}$, Ricardo Antonio Polanczyk ${ }^{1}$, Anderson \\ Mathias Holtz ${ }^{1}$, Regiane Cristina Oliveira de Freitas Bueno ${ }^{2}$, Adeney de Freitas Bueno ${ }^{3 *}$ \\ and José Roberto Gonçalvez ${ }^{1}$ \\ ${ }^{1}$ Departamento de Produção Vegetal; Centro de Ciências Agrárias; Universidade Federal do Espirito Santo; \\ 29500-000; Alegre - ES - Brasil. ${ }^{2}$ Pós-Graduação em Produção Vegetal; Universidade de Rio Verde; Rio Verde - \\ GO - Brasil. ${ }^{3}$ Embrapa Soja; Londrina - PR - Brasil
}

\begin{abstract}
This work was carried out to study the effects of adult feeding and mating on the biological potential and parasitism of Trichogramma pretiosum and T. acacioi (Hymenoptera: Trichogrammatidae) to improve their use in biological control programs. Both species presented higher parasitism and longevity whenever adults were fed. Fed and unmated T. pretiosum females led to low parasitism whereas T. acacioi females did not present parasitism whatsoever. Egg viability of T. pretiosum was similar for fed and mated individuals, but T acacioi showed lower values for this parameter when unfed and without mating. Unmated females produced only males while mated ones had more than $60 \%$ female descendents for both Trichogramma species. Therefore, mated and fed female parasitoids should be released in crop systems to increase the biological control.
\end{abstract}

Key words: Biological control, parasitoid feeding, parasitoid mating

\section{INTRODUCTION}

Egg parasitoids of the genus Trichogramma (Hymenoptera: Trichogrammatidae) are used in biological control programs of different pests because they parasitize more than 200 pest species, mainly of the Lepidoptera order (Pratissoli et al., 2004). Trichogramma spp. are largely used, but it is necessary to identify their species and strains per region, because generally they are more adapted to local climate, habitat and pest (Botelho, 1997). Species selection is based on laboratory and field trials to study the parasitoid behavior, host preference and tolerance to climate
(Pratissoli et al., 2004). However, biotic and abiotic factors, including mating and feeding, might affect these biological characteristics which could influence their efficiency (Berti and Marcano, 1991; Mcdougall and Mills, 1997; Thomson and Hoffmann, 2002).

Nectar and pollen are food source for Trichogramma adult in the field (Andow and Rish, 1987; Wellinga and Wysoki, 1989) and they affect their longevity and fecundity (Berti and Marcano, 1991; Mcdougall and Mills, 1997). These effects are important to select the best species or even strains for biological control

\footnotetext{
* Author for correspondence: adeney@ cnpso.embrapa.br
} 
program since the control effectiveness might vary between the strains of the same species.

Arrhenotoky is the most common Trichogramma reproduction type when fertilized and unfertilized eggs originate diploid females and haploid males, respectively. The complete parthenogenesis also occurs with both fertilized and unfertilized eggs originating diploid females. This may influence the control efficiency and persistency in the field. Fecundity might predict the success of parasitoids in the field (Thomson and Hoffmann, 2002). To study the parasitoid necessity of food supply previously its releasing is crucial in order to offer the best condition for the parasitoid to succeed in the field. Therefore, the objective of this study was to evaluate the effects of adult feeding and mating on the biological potential and parasitism of $T$. pretiosum and T. acacioi.

\section{MATERIAL AND METHODS}

Specimens of $T$. pretiosum and T. acacioi were obtained from the egg parasitoid mass rearing colonies. The colonies started from insects collected in tomato fields in Venda Nova do Imigrante, ES, Brazil at 750 meters (L5) and 1000 meters (L8) of altitude, respectively. Insects were reared in glass vials $(8 \times 2 \mathrm{~cm}$ diameter) using sterilized Anagasta kuehniella Zeller eggs (Parra et al., 1989).

The biological characteristics of T. pretiosum and $T$. acacioi were evaluated in climatic chamber at $25 \pm 1^{\circ} \mathrm{C}, 70 \pm 10 \%$ of relative humidity and $14: 10$ (L:D). The design was completely random with four treatments and 10 replications for each Trichogramma species. The treatments with both $T$. pretiosum and $T$. acacioi were: 1) unmated female without food; 2) unmated with food; 3) mated female without food; 4) mated with food.

Parasitoids were individualized in glass vials (3.5 $\mathrm{x} \quad 0.5 \mathrm{~cm}$ diameter) immediately after the emergence with 40 A. kuehniella eggs glued on cardboards (Hassan, 1997). One male and one female were used per replication in the treatment of mated individuals while only one female was placed per vial in the unmated treatments. Honey droplets were placed on the inner walls of the vials in the treatments with food. These vials were tapped with polyvinyl chloride (PVC) transparent film and placed in climatic chambers. Females were allowed to lay eggs and they were removed after a period of $24 \mathrm{~h}$. Eggs and female adults were observed daily until emergence and adult female deaths. The number of eggs parasitized, developmental time, viability, and female longevity were evaluated. Data were submitted to ANOVA and means were compared with Tukey test $(\mathrm{P}=0.05)$.

\section{RESULTS AND DISCUSSION}

The percentage of parasitism by $T$. acacioi unmated females with food $(53.75 \pm 7.21 \%)$ was significantly higher than that of unmated females without food $(13.00 \pm 9.05 \%)$ (Table 1). Similarly, mated females with food parasitized significantly more $(68.90 \pm 5.26 \%)$ than mated females without food $(0.00 \pm 0.00 \%)$ (Table 1$)$. The same results were observed with high parasitism by unmated fed females of $T$. pretiosum. (85.00 $\pm 9.59 \%)$ compared to unmated females without food $(64.50 \pm 14.18 \%)$ (Table 1). Mated females with food parasitized more eggs $(83.50 \pm 4.69 \%)$ than mated females without food $(23.50 \pm 12.50 \%)$ (Table 1). This showed the importance of food supply for massive rearings or adult field releases of these parasitoids in biological control programs. There are different kinds of Trichogramma release techniques (Pinto, et al. 2003) but for all of them, it is crucial to offer a source of food such as honey droplet for example to the parasitoid. These parasitoids normally feed on nectar and pollen of wild flowers in natural conditions (Andow and Rish, 1987; Wellinga and Wysoki, 1989; Hohmann et al., 2002). However, the energy and time consumed in this activity may be saved and used to increase the parasitism by offering an artificial food supply close to the releasing points in the field. Adult feeding also increased the parasitism by $T$. perkinsi and $T$. australicum (Somchoudhury and Dutt, 1988). However, this characteristic could vary from species to species because fed and unfed $T$. demoraesi females showed similar parasitism rate (Santa-Cecília et al., 1987).

Other factors besides adult feeding such as strains, parasitoid species, host quality and temperature can affect the parasitism of Trichogramma spp (Lopes, 1988; Maceda et al., 2003; Pinto and Tavares, 1992; Pratissoli et al., 2004). The 
parasitism of $T$. buesi on Pieres rapae eggs reached a maximum of $36.4 \%$ when its females were fed with honey (Abbas, 1989) and $T$. pretiosum showed $80 \%$ of parasitism on Anagasta kuehniella eggs (Tironi, 1992). These are examples of how different species fed with honew could still have different parasitism capacity.

Besides adult feeding, mating is also important because $T$. acaioi and $T$. pretiosum showed different parasitism rate for the mated and unmated females. However, it also differed for females fed or not fed. Mated females without feeding had the lowest parasitism by both $T$. pretiosum and $T$. acacioi. Unmated $T$. pretiosum females had parasitism of $64.5 \%$ without food while those mated and unfed had $23.5 \%$ parasitism (Table 1).

Table 1 - Adult feeding and mating effects on fecundity, biological potential and parasitism rate of Trichogramma pretiosum and Trichogramma acacioi (Hym.: Trichogrammatidae) $\left(25 \pm 1{ }^{\circ} \mathrm{C}, 70 \pm 10 \% \mathrm{RH}\right.$ and 14 hours L:D). Means \pm SE followed by the same letter in the column for each strain are statistically similar to each other by Tukey test $(\mathrm{P}=0.05)$.

\begin{tabular}{lcccc}
\hline Treatment & Parasitism $(\%)$ & Viability (\%) & Sex ratio & Longevity (days) \\
\hline Trichogramma pretiosum (L5) & & & & \\
\hline Unmated females without food & $64.50 \pm 14.18 \mathrm{~b}$ & $95.26 \pm 1.08 \mathrm{a}$ & $0.00 \pm 0.00 \mathrm{~b}$ & $2.50 \pm 0.22 \mathrm{c}$ \\
Unmated females with food & $85.00 \pm 9.59 \mathrm{a}$ & $93.78 \pm 3.79 \mathrm{a}$ & $0.00 \pm 0.00 \mathrm{~b}$ & $11.20 \pm 1.58 \mathrm{a}$ \\
Mated females without food & $23.50 \pm 12.50 \mathrm{c}$ & $92.53 \pm 0.39 \mathrm{a}$ & $0.64 \pm 0.09 \mathrm{a}$ & $2.60 \pm 0.16 \mathrm{c}$ \\
Mated females with food & $83.50 \pm 4.69 \mathrm{a}$ & $95.15 \pm 1.36 \mathrm{a}$ & $0.63 \pm 0.04 \mathrm{a}$ & $7.80 \pm 1.30 \mathrm{~b}$ \\
\hline Trichogramma acacioi (L8) & & & & \\
\hline Unmated females without food & $13.00 \pm 9.05 \mathrm{c}$ & $85.52 \pm 7.52 \mathrm{~b}$ & $0.00 \pm 0.00 \mathrm{~b}$ & $1.70 \pm 0.21 \mathrm{~b}$ \\
Unmated females with food & $53.75 \pm 7.21 \mathrm{~b}$ & $96.62 \pm 1.71 \mathrm{a}$ & $0.00 \pm 0.00 \mathrm{~b}$ & $7.50 \pm 0.37 \mathrm{a}$ \\
Mated females without food & $0.00 \pm 0.00 \mathrm{c}$ & - & - & $2.00 \pm 0.00 \mathrm{~b}$ \\
Mated females with food & $68.90 \pm 5.26 \mathrm{a}$ & $95.29 \pm 1.34 \mathrm{a}$ & $0.69 \pm 0.03 \mathrm{a}$ & $6.90 \pm 1.02 \mathrm{a}$ \\
\hline
\end{tabular}

Similarly, unmated T. acacioi females without food had a parasitism of $13 \%$ while this value was $0 \%$ for those mated without food (Table 1). This might be explained by the lack of energy for laying eggs that mated females certainly faced after the depletion of energy during mating, but the presence of honey prevented reduction on parasistism and even increased the parasitism for $T$. pretiosum and T. acacioi. Unmated and fed females of $T$. pretiosum had high parasitism rate $(85.00 \pm 9.59 \%)$. This value was the maximum for this species on the eggs of this host since it did not differ from mated and fed females $(83.50 \pm 4.69 \%)$ (Table 1). However, unmated and fed females of T. acacioi had lower parasitism $(53.75 \pm 7.21 \%)$ than mated and fed ones $(68.90 \pm 5.26 \%)$ (Table 1). Therefore, female parasitoids should be released after being fed and mated.

The mating or feeding did not affect egg viability of $T$. pretiosum (Table 1 ). This viability was lower for unmated females without food $(85.52 \pm 7.52 \%)$ than for unmated and fed $(96.62 \pm 1.71 \%)$ and mated and fed $(95.29 \pm 1.34 \%)$ females of $T$. acacioi. However, even the lowest viability rate $(85.52 \pm 7.52 \%)$ might be adequate for
Trichogramma species (Almeida, 1998). T. galloi had similar results on Diatraea saccharalis eggs with adult emergence of $90.47 \%$ (Cônsoli and Parra, 1994), and for $T$. distinctum on $A$. kuehniella and D. saccharalis eggs that had viability of $80.7 \%$ and $31.05 \%$, respectively (Lopes and Parra, 1991). Also, it is important to point out that mating and feeding are not the only factors that can affect egg viability. Temperature was also described in the literature as a key factor since the viability of parasitized eggs by Trichogramma spp. decreased at extremes temperatures (Pratissoli et al., 2005).

Adult feeding did not affect the sex ratio of both species but unmated females of $T$. pretiosum and $T$. acacioi produced only males when fed or not fed (Table 1). Similarly, the sex ratio was similar of $T$. pretiosum females fed or not matted (Table 1). This parameter was not evaluated for $T$ acacioi because mated females without food did not lay eggs (Table 1). However, only mated females had sex ratio different from zero for both species showing the great importance of mating to have female descendants (Table 1). This occurred because most Trichogramma species reproduced 
by arrhenotoky, with haploid males being originated by unfertilized eggs and diploid females from fertilized ones (Hohmann et al., 2002). Mated parasitoid females keep the male sperm to manipulate the sex ratio of their descendents by controlling the sperm access to their eggs during laying (Boivin et al., 2004; Doyon and Boivin, 2005). The results showed the importance to use matted females at releases, mainly when females descendants were needed. However, some species of the genus Trichogramma present reproduction by thelytoky where both fertilized and unfertilized eggs originate diploid females (Hohmann et al., 2002).

The female longevity was influenced by feeding and indirectly by mating for both species. $T$. pretiosum unmated females without food lived only $2.50 \pm 0.22$ days while unmated fed females were alive up to $11.20 \pm 1.58$ days. Also, mated females that survived $2.60 \pm 0.16$ days without food had their lifespan increased to $7.80 \pm 1.30$ days when fed (Table 1). Similarly, T. acacioi unmated females without food lived only $1.70 \pm 0.21$ days while those with access to food survived $7.50 \pm 0.37$ days. $T$. acacioi mated females without food that lived $2.00 \pm 0.00$ days, survived $6.90 \pm 1.02$ when fed (Table 1). The increase in longevity is important to allow this biological control agent to find the host in the field. This increases the chances of a biological control program using Trichogramma to succeed. The longevity of $T$. minutum also increased when fed. The females fed with honey lived 26.4 days while those without food source lived only 3.5 days (Leatemia et al., 1995). Adults of T. carverae and T. brassicae lived longer with food (Gurr and Nicol, 2000). However, not all species or strains of the genus Trichogramma have longer longevity when fed which shows the importance of studies addressing this subject. $T$. demoraesi females had similar longevity of 11 days whether fed or not fed (Santa-Cecília et al., 1987).

Mating also influenced the adult longevity, mainly for $T$. pretiosum. Unmated and fed females lived $11.20 \pm 1.58$ days and mated lived only $7.80 \pm 1.20$ (Table 1). However, this decrease in longevity of mated females was more related to the depletion of the body energy during mating. This suggested that unmated females could be also used for biological control, mainly when the second generation of the parasitoid in the field is not of great importance. This might be the example of annual crops. However, it is important to consider that unmated females just produce males what can compromise the maintenance of the parasitoid in the environment. This would be probably prejudicial to the success of the biological control, mainly regarding to perennial crops. Moreover, the adult longevity of Trichogramma might vary with the host (Bai et al., 1995) or temperature which was normally inversely proportional to the longevity (Abbas, 1989; Maceda et al., 2003). Thus, it could be concluded that mated and fed females should be released for the biological control in the field against lepidopteran pests. Results showed increased efficacy of $T$. pretiosum and $T$. acacioi in the field and gave important guidelines for mass rearing and parasitoid releases.

\section{RESUMO}

Os efeitos do acasalamento e alimentação no potencial biológico e parasitismo de Trichogramma pretiosum e Trichogramma acacioi (Hymenoptera: Trichogrammatidae), foram estudados objetivando-se aprimorar o uso dessas espécies no controle biológico. O parasitismo e longevidade dos adultos de ambas as espécies foram maiores para fêmeas alimentadas e o parasitismo foi nulo e baixo para fêmeas acasaladas e não-alimentadas de $T$. acacioi e $T$. pretiosum, respectivamente. A viabilidade de ovos parasitados por $T$. pretiosum foi semelhante entre os tratamentos, mas para T. acacioi houve uma menor viabilidade do parasitismo realizado por fêmeas sem acasalamento e sem alimento. Descendentes de $T$. pretiosum e $T$. acacioi sem acasalamento produziram apenas machos, enquanto fêmeas acasaladas tiveram mais de $60 \%$ dos descentes fêmeas para as duas espécies de Trichogramma. Portanto, fêmeas acasaladas e alimentadas devem ser liberadas para o controle biológico.

\section{ACKNOWLEDGEMENTS}

We thank the "Conselho Nacional de Desenvolvimento Científico e Tecnológico (CNPq)", "Coordenação de Aperfeiçoamento de 
Pessoal de Nível Superior (CAPES)", and "Fundação de Amparo à Pesquisa do Estado de Minas Gerais (FAPEMIG)" for grants and scholarships, and the professors of the "Universidade de São Paulo (ESALQ/USP)" for having identified the species.

\section{REFERENCES}

Abbas, M. S. T. (1989), Studies on Trichogramma buesi as a biocontrol agent against Pieris rapae in Egypt. Entomophaga, 34, 447-451.

Almeida, R. P. (1998), Controle de qualidade na produção de Trichogramma, p. 26-34. In R. P. Almeida, C. A. D. Silva and M. B. Medeiros (eds.), Biotecnologia de produção massal e manejo de Trichogramma para o controle biológico de pragas. Campina Grande, EMBRAPA-CNPA, 61p.

Andow, D. A. and Risch, S. J. (1987), Parasitism in diversified agroecosystems: Phenology of Trichogramma minutum (Hymenoptera: Trichogrammatidae). Entomophaga, 32, 255-260.

Bai, B.; Çobanoglu, S. and Smith, S. M. (1995), Assessment of Trichogramma species for biological control of forest lepidopteran defoliators. Entomologia Experimentalis et Applicata, 75, 135145.

Berti, J. and Marcano, R. (1991), Effect of time of host absence on parasitism by Trichogramma pretiosum Riley (Hym.: Trichogrammatidae). Boletin de Entomologia Venezoelana, 6, 5-10.

Botelho, G. R. (1997), Eficiência de Trichogramma em campo. In: Parra, J. R. P. and Zuchi, R. A. (Ed.). Trichogramma e o controle biológico aplicado. Piracicaba: FEALQ, p.303-318.

Boivin, G.; Jacob, S. and Damiens, D. (2004), Spermatogeny as a life history index in parasitoid wasps. Oecologia, 35, 371-378.

Cônsoli, F. L. and Parra, J. R. P. (1994), Efeito do fotoperíodo na biologia de Trichogramma galloi Zucchi. Anais da Sociedade Entomológica do Brasil, 23, 467-472.

Doyon, J. and Boivin, G. (2005), The effect of development time on the fitness of female Trichogramma evanescens. Journal of Insect Science, 5, $1-5$.

Gurr, G. M. and Nicol, H. I. (2000), Effect of food on longevity of adults of Trichogramma carverae Oatman and Pinto and Trichogramma nr brassicae Bezdenko (Hymenoptera: Trichogrammatidae). Australian Journal of Entomology, 39, 185-187.
Hassan, S. A. (1997), Seleção de espécies de Trichogramma. In: Parra, J. R. P. and R. A. Zucchi. Trichogramma e o controle biológico aplicado. Piracicaba: FEALQ, cap.7, p. 183-206.

Hohmann, C. L.; Luck, R. F. and Stouthamer,R. (2002), Effect of Wolbachia on the survival and reproduction of Trichogramma kaykai Pinto and Stouthamer (Hymenoptera: Trichogrammatidae). Neotropical Entomology, 30, 607-612.

Hohmann, C. L.; Luck, R. F.; Oatman, E. R. and Platner, G. R. (1989), Effects of different biological factors on longevity and fecundity of Trichogramma platneri Nagarkatti (Hymenoptera: Trichogrammatidae). Anais da Sociedade Entomologica do Brasil, 18, 61-70.

Leatemia, J. A.; Laing, J. E. and Corrigan, J. E. (1995), Production of exclusively male progeny by mated, honey-fed Trichogramma minutum Riley (Hym., Trichogrammatidae). Journal of Applied Entomology, 119, 561-566.

Lopes, J. R. S. 1988. Estudos bioetológicos de Trichogramma galloi Zucchi, 1988 (Hym.: Trichogrammatidae) para o controle de Diatraea saccharalis (Fabr., 1794) (Lep.: Pyralidae). 1988. Dissertação (Mestrado) - Escola Superior de Agricultura "Luiz de Queiroz", Universidade de São Paulo, Piracicaba, 1988.

Lopes, J. R. S. and Parra, J. R. P. (1991), Efeito da idade de ovos do hospedeiro natural e alternativo no desenvolvimento e parasitismo de duas espécies de Trichogramma. Revista de Agricultura, 66, 221-244.

Maceda, A.; Hohmann, C. L. and Santos, H. R. (2003), Temperature effects on Trichogramma pretiosum Riley and Trichogramma annulata De Santis. Brazilian Archives of Biology and Tecnology, 48, 523-529.

Mcdougall, S. J. and Mills, N. J. (1997), The influence of hosts, temperature and food sources on the longevity of Trichogramma platneri. Entomologia Experimentalis et Applicata, 83, 195-203.

Pak, G. A. (1988), Selection of Trichogramma for inundative biological control. Wageningen, 224p.

Parra, J. R. P.; Lopes, J. R. S and Sales Jr., O. (1989), Metodologia de criação de Anagasta kuehniella (Zeller, 1879) para a produção massal de Trichogramma spp. Anais das Sociedade Entomológica do Brasil, 18, 403-415.

Pinto, A. S.; Parra, J. R. P.; Oliveira, H. N. and Arrigoni, R. D. B. (2003), Comparação de técnica de liberação de Trichogramma galloi Zuchi (Hymenoptera: Trichogrammatidae) para o controle de Diatraea saccharalis (Fabricius) (Lepidoptera: Crambidae). Neotropical Entomology, 32, 311-318. 
Pinto, F. and Tavares, J. (1992), Longevity and parasitic capacity of the azorean type of Trichogramma cordubensis Vargas; Cabello (Hymenoptera: Trichogrammatidae). Paper presented at $3^{\text {th }}$ International Symposium on Trichogramma and other egg parasitoids, 3, San Antonio. Proceedings...Paris: INRA, 1992. p. 89-91.

Pratissoli, D.; Zanuncio, J. C.; Vianna U. R.; Andrade, J. S.; Zanotti, L. C. and Silva, A. F. (2005), Biological characteristics of Trichogramma pretiosum and Trichogramma acacioi (Hym: Trichogrammatidae), parasitoids of the avocado defoliator Niperia panacea (Lep.: Geometridae), on eggs of Anagasta kuehniella (Lep.: Pyralidae). Brazilian Archives of Biology and Technology, 48, 713.

Pratissoli, D.; Holtz, A. M.; Gonçalves, J. R.; Vianna, U. R. and Bellini, L. L. (2004), Efeito da ausência de hospedeiro e de alimento sobre aspectos biológicos de Trichogramma pretiosum Riley (Hymenoptera: Trichogrammatidae). Acta Scientiarum, 26, 281-286.

Santa-Cecília, L. V. C.; Matioli, J. C.; Sousa, B. (1987), Aspectos da biologia de Trichogramma demoraesi Nagajara, 1983 e contribuições no manejo de criações massais deste parasitóide em ovos de Anagasta kuehniella (Zeller, 1879). Anais da Escola Superior de Agricultura "Luiz de Queiroz", 44, 1607-1625.
Somchoudhury, A. K. and Dutt, N. (1988), Evaluation of some flowers as a nutritional source of Trichogramma spp. Indian Journal of Entomology, 50, 371-373.

Thomson, L. J. and Hoffmann, A. A. (2002), Laboratory fecundity as predictor of field success in Trichogramma carverae (Hymenoptera: Trichogrammatidae). Journal of Economic Entomology, 95, 912-917.

Tironi, P. (1992), Aspectos bioecológicos de Trichogramma pretiosum Riley, 1879 e Trichogramma atopovirilia Oatman and Platner, 1983 (Hym.: Trichogrammatidae) como agentes de controle biológico de Helicoverpa zea (Boddie, 1850) (Lep.: Noctuidae). Lavras: ESAL. 74p. Dissertação de Mestrado.

Wellinga, S. and Wysoki, M. (1989), Preliminary investigation of food source preferences of the parasitoid Trichogramma platneri Nagarkatti (Hymenoptera, Trichogrammatidae). Anzeiger für Schadlingskunde Pflanzenschutz Umweltschutz, 62, 133-135. 